\title{
Clinical epidemiology and molecular analysis of hospitalized children with hand-foot and mouth disease during 2009 in Shanghai
}

\author{
$H Y u^{*}, F X Y a n$ \\ From International Conference on Prevention \& Infection Control (ICPIC 2011) \\ Geneva, Switzerland. 29 June - 2 July 2011
}

\section{Introduction / objectives}

We retrospectively analyzed the clinical features and epidemiology of 1386 children with hand-foot and mouth disease during 2009 at Children's Hospital of Fudan University and investigated some risk factors with fatal cases. Besides, we also identified the pathogen of 116 patients.

\section{Methods}

All the clinical records and laboratory results were collected. A retrospective study was performed and reverse transcriptase-polymerase chain reaction (PCR) assay was used to identify the pathogen.

\section{Results}

A total of 1386 patients were enrolled in this report, with onset median age 25 months. Among them, 62.4\% patients aged between 1 to 3 years and $67 \%$ patients came from rural area. Fever (88.3\%), rashes (99.2\%), cough (22.5\%), vomiting (25.4\%) were the most frequent symptoms while myoclonus jerk, hypertension and tachycardia mainly occurred in those fatal cases. Fatal patients had higher fever, white-blood-cell counts and blood glucose compared to those in stage 1and 2 $(\mathrm{P}<0.05)$, but not in $\mathrm{C}$-reaction protein or cerebrospinal fluid white-blood-cell counts. Besides these, we also made etiologic analysis of 116 patients to identify 76 cases of enterovirus 71 infection, 4 cases of CA16 infection and 8 cases of other enterovirus infection. And we found the Shanghai EV71 belonged to subgenotype C4 by the phylogenetic analysis.

Department of Infectious Diseases, Children's Hospital of Fudan University, Shanghai, China

\section{Conclusion}

The children under 3 years especially from rural area are susceptible to the HFMD infection. Persistent high fever and frequent vomiting, or myoclonus jerk, hypertension and tachycardiamay indicate severe tendency. Some laboratory examinations can help us find the fatal cases earlier. But a early pathogen identification especially enterovirus 71 is so important.

\section{Disclosure of interest}

None declared.

Published: 29 June 2011

doi:10.1186/1753-6561-5-S6-P46

Cite this article as: Yu and Yan: Clinical epidemiology and molecular analysis of hospitalized children with hand-foot and mouth disease during 2009 in Shanghai. BMC Proceedings 2011 5(Suppl 6):P46.

Submit your next manuscript to BioMed Central and take full advantage of:

- Convenient online submission

- Thorough peer review

- No space constraints or color figure charges

- Immediate publication on acceptance

- Inclusion in PubMed, CAS, Scopus and Google Scholar

- Research which is freely available for redistribution 